Relations industrielles

Industrial Relations

\title{
Table de l'année 1946-47 (numéros 1-10)
}

Volume 2, numéro 10, juin 1947

URI : https://id.erudit.org/iderudit/1023886ar

DOI : https://doi.org/10.7202/1023886ar

Aller au sommaire du numéro

Éditeur(s)

Département des relations industrielles de l’Université Laval

ISSN

0034-379X (imprimé)

1703-8138 (numérique)

Découvrir la revue

Citer cet article

(1947). Table de l'année 1946-47 (numéros 1-10). Relations industrielles /

Industrial Relations, 2(10), 8-8. https://doi.org/10.7202/1023886ar

Tous droits réservés (C Département des relations industrielles de l’Université Laval, 1947
Ce document est protégé par la loi sur le droit d'auteur. L'utilisation des services d'Érudit (y compris la reproduction) est assujettie à sa politique d'utilisation que vous pouvez consulter en ligne.

https://apropos.erudit.org/fr/usagers/politique-dutilisation/ 
$8^{\circ}$ the disbursements made by it during such fiscal year, including the purposes for which made;

$9^{\circ}$ proof that it has furnished to all of its members copies of its financial report. »

Therefore, it is not surprising that the well-known catholic review «AMERICA》, in its May 24 issue, maintains a wise reserve as regard this proposed legislation. It goes on to say, after underscoring its main aspects, that «despite certain constructive features, the net effect of this bill is to weaken the power of organized labor and not merely to discipline it. Its underlying philosophy is not encouragement of organization, but at best, neutrality; at worst, opposition. The bill thus reverses the approach to industrial relations enshrined in the National Labor Relations Act. If the law could be enforced, which is doubtful, it seems to us that labor unions would gradually lose their cohesion, become fragmentized and decline in numbers and power. Some of them, especially in industries which have never accepted the philosophy of the Wagner Act, might be destroyed. For these reasons, we believe that President Truman ought to veto the bill. »

It will prove quite interesting to follow the development of American labour legislation during the course of the next few months. What will be the outcome of the joint session of the Senate and House of Representatives?

Should a bill be passed, would it satisfactorily meet the approval of President Truman ? Whatever may be the results, the problem actually being solved in the U. S. is an important one to Canada which has, for the last ten years, drawn inspiration from the principles laid down in the Wagner Act on freedom of association.

Gérard TREMBLAY

\section{TABLE DE L'ANNÉE 1946-47 ( numéros 1-10)}

Agent d'affaires du syndicat, L, - Joseph Pelchat, No 7, mars. Agreement Act, The Collective - Marcel Forget, Nos 7, 9 and 10, March, May and June.

Apprentissage, Une politique de l' - Gérard Tremblay, Nos 2 et 4 , octobre et décembre.

Arbitrage obligatoire, Conflits du travail et - Gérard Dion, No 6, février.

Associations ouvrières chrétiennes de l'Allemagne, L'interconfessionnalité des - Egbert Munzer, No 2, octobre.

Capacité de payer et détermination du salaire - Raymond Gérin, Nos 3 et 6, novembre et février.

Code du travail, Le - No 5, janvier.

Code, The Labour - No. 5, January.

Collaboration patronale-ouvrière, L'extension de la - Jean-Pierre Després, No 7, mars.

Collective Agreement Act, The - Marcel Forget, Nos. 7, 9 and 10, March, May and June.

Comités paritaires, La fédération des - Marcel Forget, No 9, mai.

Communistes et les unions ouvrières, Les - Gérard Dion, No 9, mai.

Conditions de travail, Nouveaux concepts de - J. O'ConnellMaher, No 1, septembre.
Conflits du travail et arbitrage obligatoire - Gérard Dion, No 6, février.

Congrès des relations industrielles - Nos $5,6,7$ et 8 , janvier, février, mars et avril.

Convention collective, Loi de la - Marcel Forget, Nos 7, 9 et 10 , mars, mai et juin.

Directeur de personnel, Le - T. Roger McLagan, No 9, mai.

Economic capacity and the determining of wages - Raymond Gérin, Nos. 4 and 6, December and February

Faits, Principes et - Georges-Henri Lévesque, o.p., No 2, octobre.

Facts, Principles and - Georges-Henri Lévesque, o.p., No. 2, October.

Fédération des comités paritaires, La - Marcel Forget, No 9, mai.

Grèves, Réflexions sur les - Gérard Tremblay, No 1, septembre.

Griefs sous le régime de la convention, Du règlement des Donat Quimper, No 9, mai.

Industrial Peace in Quebec - Gérard Dion, No. 4, December.

Industrial relations Convention - Nos. 7 and 8, March and April.

Industrial relations, Research work in - Gérard Dion, No. 3, November.

Interconfessionnalité des associations chrétiennes de l'Allemagne, L' - Egbert Munzer, No 3, novembre.

International Labour Organization - Jean-Pierre Després, No. 1, September.

Labour Code, The - No 5, January.

Liberté syndicale, Pratiques interdites et - Gérard Tremblay, No 10, Juin.

Organisation internationale du travail - Jean-Pierre Després, No 1 , septembre.

Organisation syndicale. Faut-il prévenir le patron? - Omer Genest, No 6, février.

Paix industrielle dans le Québec - Gérard Dion, No 4, décembre. Participation ouvrière, La - Jean-Pierre Després, No 5, janvier. Peace in Quebec, Industrial - Gérard Dion, No. 4, December.

Personnel Manager, The - T. Roger McLagan, No. 9, May.

Pratiques interdites et liberté syndicale - Gérard Tremblay, No 10 , juin

Prévenir le patron, Faut-il - Omer Genest, No 6, février.

Principes et faits - Georges-Henri Lévesque, o.p., No 2, octobre. Psychologie industrielle - Arthur Tremblay, No 5, janvier.

Fiecherches en relations industrielles - Gérard Dion, No 2, octo!,

Règlements d'atelier. (Cas pratiques) - Donat Quimper, No 6, février.

Règlement des griefs sous le régime de la convention collective, Du - Donat Quimper, No 9, mai.

Kelations ouvrières, Loi des - Marius Bergeron, No 2, octobre.

Research work in industrial relations - Gérard Dion, No. 2, October.

Rules, Shop. (Practical cases) - Donat Quimper, No 6, February.

Salaire, Capacité de payer et détermination du - Raymond Gérin, Nos 4 et 6, décembre et février.

Sécurité syndicale, Aspect moral des clauses de - Gérard Dion, No 8, avril.

Sécurité syndicale dans les conventions collectives de la province de Québec, Clauses de - Gérard Dion, No 2, octobre.

Sécurité syndicale et l'employeur, La - Arthur Drolet, No 8, avril.

Sécurité syndicale et le syndicat, La - Gérard Picard, No 8, avril.

Shop rules. (Practical cases) - Donat Quimper. No. 6, February. Strikes, Reflexions on - Gérard Tremblay, No. 1, September.

Syndicalisme patronal, A propos de - Gérard Dion, No 1, septembre.

Travail, Le Code du - No 5, janvier.

Unions ouvrières, Les communistes et les - Gérard Dion, No 9, mai.

Union securité provisions in the collective agreements of the Province of Quebec - Gérard Dion, No 2, October.

W'orking conditions, New concepts of - J. O'Connell-Maher, No. 1, September.

Wages, Economic capacity and the determining of - Raymond Gérin, Nos. 4 and 6, December and February. 